\title{
Public Value Management: An Emerging Paradigm in Public Administration
}

\author{
Malang B.S. Bojang \\ Political Science and Public Administration Department, \\ Faculty of Economics and Administrative Sciences, Kocaeli University, Turkey \\ malangbsbojang@gmail.com \\ ORCID: https://orcid.org/0000-0003-0041-269X
}

\begin{abstract}
In 1975, Nicholas Henry puts forward five paradigms for public administration. These paradigms demonstrate the historical development of public administration since Woodrow Wilson's famous article. The existence of competing paradigms in public administration enhances theoretical development within the discourse. Public value management has brought a new dimension to the discourse. The purpose of this study is to investigate the paradigmatic shift in public management and to determine if the 'Public Value Management' represents an emerging paradigm in public administration. The paper attempts to answer two main questions: (a) Does public value management represent a new paradigm in the field of public administration? (b) Is public value management the future of public administration? To answer these questions, the study followed a historical approach to provide an accurate description and analysis of the current state as well as predicting its future course. Data for this study has been collected through a primary scoping of the literature on public administration. This paper shows that public value is not only an emerging paradigm in public administration but also the future. The study also found out that public value is the next big thing for governments aiming to deliver better public service. The public value paradigm is centered around the needs of the public as citizens, as well as consumers, the creation of value rather than achieving individual outcomes. It is more than the aggregation of individual needs with deliberation as to what constitutes public value at its core. In answering the aforementioned questions, the paper endeavor to establish the focus of public value management paradigm within the public administration field. The study adds value to the literature and theoretical development of public value.
\end{abstract}

Keywords: Public Administration, Public Administration Paradigms, Public Value Management, e-Governance

Published by:

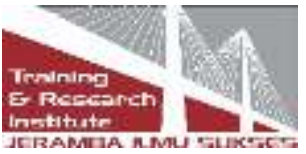

Page 225 
Vol. 2, No. 4, November 2021

\section{How to Cite:}

Bojang, M. B. S., (2021). Public value management: an emerging paradigm in public administration. International Journal of Business, Management and Economics, 2(4). 225 - 238. DOI: https://doi.org/10.47747/ijbme.v2i4.395

\section{Introduction}

In 1968 Dwight Waldo pronounced that public administration has an identity crisis. According to Rutgers (2010), the alleged crisis has much to do with the scope and theory of the discourse. This implies understanding and explaining the connection between the subject matter and the object of study. The debate is not only on the boundaries of the study but also on the status of public administration. According to Waldo (1968), the scope of the theories in public administration has both practical and theoretical limitations. This is because public administration deals with complex ideas that portray a normative image of human society. Therefore, it is difficult to pinpoint a specific paradigm, well-articulated ideas, core questions, coherent methodology, or approaches for the study of public administration. I argued that the label 'identity crisis' is perhaps needed as it captures the advancement and betterment of the study.

It is now more than five decades since Woodrow Wilson wrote his famous article 'The study of Administration' where he states that 'it is easier to frame a constitution than to run it'(Wilson, 1887). There is so much in Wilson's article that sounds modern. Wilson (1887) highlights the significance of governmental administration. According to Wilson (1887), 'Administration is not only the operative mechanism of the government but also the most visible executive action' (Wilson, 1887). This implies that the state can meet its purpose only through an efficient administrative instrument. As Marshall Dimock beautifully asserts: "Public administration is a process or a theory, not merely an accumulation of detailed facts. Administration emphasizes on implementing the task of government successfully at a minimal cost both in resources and of energy" (Dimock, 1937:29).

As an academic discipline, public management has gone through several transformations from Classical Public Administration to New Public Management (NPM) and Governance paradigm (Mukonza, 2014). This evolution has affected the character of governments, so has its ability to relate with various actors in society. The purpose of this study is to investigate the paradigmatic shift in public administration and to determine if the 'Public Value Management' represents a new management paradigm in the discourse. The research seeks to answer two questions: Does public value management represent a new paradigm in the field of public administration? And is public value management the future of public administration? In this paper, public value management is viewed as a paradigm that needs serious attention from researchers and practitioners for theoretical and empirical development.

This paper is organized as follows: first, conceptual clarification of public value, and at the same time distinguishing it from private value, common good, public interest. The paper attempted to trace the historical origin of public value discussion. This is followed by outlining the different paradigms in public administration, leading to the central argument of this study; public value as 
the new paradigm in public administration. Then, the conclusion and recommendations for future studies are highlighted.

\section{Origin Of Public Value}

Public value management is a hot topic in public administration and the concept has been used by numerous scholars in the literature (Alford \& O'Flynn, 2009; Benington, 2009; Bojang, 2021; Jørgensen \& Bozeman, 2007; Moore, 1995; Rutgers, 2015). However, studies on 'Values' in public administration are not new as Waldo's (1984) “Administrative States" discussed values though he did not explicitly use the term. The same is true for Simon's (1976) "Administrative Behavior" which highlights the difference between fact-value. What is new is the coming of 'Public Value' which is extremely popular (Rhodes \& Wanna, 2007). The public value concept is important because it complements and resolves the deficit of democracy by engaging the public in determining what is most valued. Jørgensen \& Bozeman (2007) pronounced public value as the most significant topic in administration and policy studies, while for others, it is regarded as an important theoretical and practical "guiding concept" (Rutgers, 2015). It has been heralded by various scholars as an administrative practice (Bozeman, 2019; Jørgensen \& Bozeman, 2007; Jørgensen \& Rutgers, 2015); as "a hard-edged tool for decision-making" (Alford \& O'Flynn, 2009), and “a rigorous way of defining, measuring and improving performance". The extreme popularity of public value made other researchers declaring it as a "new era in public management" (Stoker, 2006; Talbot, 2017).

The public value management concept was propounded by Harvard University Professor Mark Moore in 1995 as a response to the "New Public Management" which at the time was the darling of public management and influences public policy of countries. The concept of public value focused on the preferences and aspirations of the citizens as well as consumers, the generation of desirable outcomes rather than achieving individual needs, and public value is more than the accumulation of individuals desires with discussion as to what constitutes public value at its core (Turrell, 2017). Moore (1995) challenged the neo-liberal thinking on three issues:

The role of government: Moore (1995) argues that the role of government should go beyond mere supervisor and service provision to the public, to value creation in the public sector. The role of public managers (service managers): Public managers should seek out opportunities that are most valuable to the public. It implies using government resources to create desire social outcomes for citizens.

The techniques needed by service managers: Benington and Moore (2011) argued that service managers' skills and techniques to work with relevant stakeholders to ensure good policy choices in the interest of the public and at the same time legitimate to improve socially desirable outcomes (Bromell, 2012).

Despite the popularity and optimism of public value, the term remains elusive, problematic, and unclear (Meynhardt, 2009; O'Flynn, 2007). There has yet to be a consensus on the definition of public value. Public value is a generic concept that's everything to people (Rhodes \& Wanna, 2007). For Rutgers (2015), public value is not just a generic term but a "pantheon concept." The pantheon concept is used as a metaphor referring to a collection of possible concepts dealing 
with public value. The elusiveness of public value makes it even more popular among scholars (Rhodes \& Wanna, 2007). However, scholarly attempts are made to define public value. For example, Meynhardt (2009) defines public value as "the value that impacts on values about the public"; Benington (2009) defines it as "what 'the public' values and what adds value to "the public sphere""; while Bozeman (2007) defines it as a "normative agreement about the rights, benefits, and obligations of citizens to society, the state, and one another" (Bozeman, 2007:13). In this paper, "public values are explicit values that concern "the good society" or "the general interest," that is, the sustainability of society and the well-being of its members, irrespective of immediate personal preferences or interests" (Rutgers, 2015:39).

An in-depth investigation of the origin of public value is to question the ontology of social science. Meynhardt (2009) concludes that "public value starts and ends within the individual". This conclusion is drawn based on his psychological approach to individual values. Bozeman (2007) disagrees with an individualistic economic approach to public values. Similarly, Moore (1995) also argued that public value is the collective and draws on democracy and public interest. Rutgers (2015) intelligently argues that "citizen satisfaction is a possible public value, but a person's satisfaction with some product or service is not, nor the simple sum of such perceptions". Therefore, public value can be located in the collective 'We' rather than individual interest.

\section{Literature Review}

\subsection{Paradigms Of Public Administration}

Since Woodrow Wilson's famous essay on the study of administration, Henry (1975) provides a solid argument and discussed the evolution of public administration through the five paradigms put forward (Mukonza, 2014). The birth of public administration is associated with Woodrow Wilson's seminal article though debatable. In his book titled 'Public Administration and Public Affairs', Nicholas Henry (1975) gives a comprehensive description of the five paradigms. With the development of American Public Administration, other paradigms emerged-i.e. NPM, Good Governance, and Public Value Management. As an academic field, the development of public management may be regarded as a series of nine (9) overlapping paradigms:

\section{Paradigm 1: The Politics/Administration Dichotomy, 1900-1926}

The Politics/Administration dichotomy corresponds with the earlier writings of Frank J. Goodnow and Leonard D. White. In his book, Goodnow (1900) stated the two functions of government, which are 'Politics and Administration'. Politics, said Goodnow, "is about policies, and state will," while the administration "is about the implementation of these policies" (Henry, 1975:379). With the advent of separation of powers, the legislative organ formed laws and policies, while the executive implemented those policies and laws impartially and apolitically. Similarly, Woodrow Wilson laid a compelling argument of this dichotomy by stressing that 'administration is a business field'. Wilson (1887) calls for a total separation of politics from administration and suggests that "administration lies outside the proper sphere of politics" (Wilson, 1887:210). Also, Dwight Waldo pointed out that "administration ought to be separated 
from politics, and that politics should not encroach on administration". Waldo relates Politics/Administration separation to the corresponding Value/Fact dichotomy.

This paradigm's central focus is on the government's bureaucracy. With the 'Public Service Movement' in Universities across America, scholars began to focus more on administrative studies. Political Science then, was concerned with training for citizenship, law, and recruiting people for a government position. As a sub-field of political science, public administration locus was perceived to train public administrators. Public administration legitimacy came in the 1920s with the publication of the first textbook titled 'Introduction to the Study of Public Administration' in 1926 by Leonard D. White. During this period, administrative skills are needed to purify a rotten civil service.

\section{Paradigm 2: The Principles of Administration, 1927-1937}

Willoughby (1927) published a book on administrative principles — which was considered to be the second fully-fledged text in the public administration. This book emphasizes specific management principles that could be learned scientifically so managers would become specialists in their fields. In the 1930s to early 1940s, public administrators were in high demand for their managerial skills from government and business alike. In addition, Gulick and Urwick (1937) put forward their classic text on management principles to support public managers perform the following functions. For them, the role of managers includes planning of tasks, organizing of the task, staffing, directing staffs to accomplished goals, coordinating staffs and departments, reporting and budgeting of the organization (Bojang, 2020; cited Gulick, 1937:13).

The principles of administration had their first conceptual challenged the following year. In the text 'Administrative Behavior' Herbert A. Simon laid down two compelling criticism of the field. First, it was argued that politics and administration could never be separated, and the other criticism was that administrative principles were logically inconsistent (Henry, 1975). According to Simon, administrative science is inconsistent proverbs of common sense and not scientific. He proposed administrative studies to be based on scientific principles and laws and equally called for the separation of facts from value judgments (Gruening, 2001:4). However, the politics/administration separation had been abandoned by young creative scholars in the midcentury. This abandonment led to the epistemological identity of public administration. Some would argue that identity has yet to be found. In 1947, Simon offered an alternative paradigm in his essay 'The Science of Public Administration' where he argued that scholars ought to be concerned with advancing 'pure science of administration' and 'prescribing for public policy'. Although Simon's proposal was rigorous and normative, it puts off a host of scholars in public administration and political science (Henry, 1975:380).

\section{Paradigm 3: Public Administration as Political Science, 1950-1970}

In this era, the emphasis was on revisiting the object and scope of the study. Researchers have tried to re-established the linkage between political science and public administration. Most of the writings in 1950 viewed public administration as an interesting area or even synonym to political science. Public administration began a downhill spiral in this era (Henry, 1975). In 
1967, public administration was no longer considered as a sub-field of political science, and scholars of this generation were left out. According to Waldo (1968), the attitudes of political scientists were that of 'indifference' and 'hostility' that public administration scholars felt unwelcome in the house of their youths. Also, scholars at this time challenged and question Wilson's Politics/Administration dichotomy.

\section{Paradigm 4: Public Administration as Administrative Science, 1956-1970}

This paradigm came into being mainly because of the contempt shown to the field by political scientists. This paradigm offers specialization and argued that administration is administration irrespective of where it is found. In this period, the academicians of administrative studies were concerned with the focus of the discourse. It was suggested that organizational theory should be the motivation of administrative studies (Henry, 1975). In the 1960s, 'organization development' started its swift upsurge as a specialty of administrative science. One of the dilemmas of this paradigm is that it tends to delink and eliminate 'Public' in administration, which could mean becoming a sub-field under Business Administration. Part of this problem was the distinction between the public and the private sectors in American society (Mukonza, 2014).

\section{Paradigm 5: Public Administration as Public Administration, 1970-?}

During this era, a considerable amount of progress has been made with renewed validity. Techniques of management science learned have been reflected in organizational analysis. This paradigm saw the distinction between public and private spheres wane away. Furthermore, public administrationists at the time have been more concerned with public policy-making, political economy, and performance measurement (Henry, 1975:383). Dwight Waldo organized a conference (The Minnowbrook Conference) in which he invited young scholars to discussed the future direction of the discourse. This conference started the New Public Administration (NPA), combining ideas from human relations and the political faction of management. The participants in the conference called for a new direction and that administrative science ought to focus beyond efficient administration to more democratic values (Gruening, 2001). In the public administration paradigm, scholars strived to build an autonomous curriculum with epistemological uniqueness. The efficacy of public administration in society appeared to be well appreciated and this was a good reason for the field to be autonomous.

\section{Paradigm 6: Public Administration as New Public Management, (1991-?)}

The focus during this period was on how to make the government more economic and efficient in its provision of goods and services to the public (Bojang, 2020b; Mukonza, 2014). By the late 1970s to early 1980s, key figures like Margaret Thatcher of the United Kingdom and local governments in America started pushing for private sector-led-NPM (Bojang, 2020b; Gruening, 2001; Hood, 1991). According to Hood (1991), NPM emerged from two theoretical streams of ideas. First is the 'new institutional economics' of public choice, and principal-agent theory; and second is a business-type 'managerialism' in the public sector (Hood, 1991, 1995). The key elements of NPM include large-scale privatization, corporatization, and commercialization; market-led growth; a shift to change management; reduce government 
spending; a shift to output control; more competition; decentralization; performance measurement (Bojang, 2020b; Hood, 1991).

The New Public Management is a series of novel reforms to public administration and management that emerged in several Western countries in the 1980s. The NPM paradigm arose in reaction to the limitations of the classical public administration in adjusting to the demands of a competitive market economy. The public sector borrows a private sector approach to management and led to significant changes in the public sector approach, especially in management practices, efficiency-focused, accountability, and privatization of ineffective public enterprises. Many countries have adopted NPM reforms, only a few have implemented wholesale NPM reforms.

\section{Paradigm 7: Public Administration as Governance (1995-?)}

The NPM overly focuses on economic efficiency with emphasis on individual preference. The governance paradigm challenged this notion and rather argued that collective preferences for the society should supersede individual choices. Recently, there has been a check on government service provisions and delivery to society. Because of shifting demographic structures, coupled with the advancement of science and technology, citizens' aspirations are increasingly high, which must be solved by the government more cost-effectively. This pressure on the government led to the new reform agenda. Governments are seeking alternative ways to deliver quality public services to society (Dickinson, 2016:41). Against this background, the reform for governance has received significant attention. In the past years, governance reform responded to failing big governments and market deficiency.

This paradigm challenged the liberal economic philosophy and argued that government should be run like a democracy (Denhardt \& Denhardt, 2007). Administrators now emphasize "listening" to the public rather than "telling," and by "serving" rather than "steering." This paradigm calls for the co-creation of what is most desired by the citizens and public officials. This movement in public administration is what Denhardt \& Denhardt (2007) called "New Public Service". The New Public Service stressed the interest of the public, democratic values and co-production, and inclusiveness. Therein lies the soul of public administration. As Denhardt \& Denhardt (2007) intelligently articulate:

"What is most significant, and most valuable about public administration is that we serve citizens to advance the common good. Ultimately, for public administrators, what matters is not how efficiently we have done our jobs, but how we have contributed to a better life for all" (Denhardt \& Denhardt, 2007:4).

\section{Paradigm 8: Public Administration as e-Governance}

Electronic Governance (shortly, e-Governance) is regarded as part of the reform strategies of the NPM in 1980. It is the introduction of Information and Communication Technologies (ICTs) in governance to achieve greater delivery of services to the public. The term e-Governance emerged in the late 1990s through information technology and the internet has been in administration since the 1970s (Kraemer, et al, 1978; Danziger and Andersen, 2002; Grönlund and Horan, 2004:714). It is vital to note that e-Governance goes beyond internet use in government to a 
reform strategy for the effective functioning of the administration. It was part of the reform package of NPM in the late 1980s to enhance efficiency and improve outcomes through automation.

e-Governance makes governments relevant in this digital era and therefore, governments can either be 'in e-Government or out of e-Government'. It is a necessity to meet contemporary challenges faced by governments globally (Bojang, 2019, 2020a). The adoption of e-Governance in public administration has enhanced democracy and good governance. e-Governance can be seen as belonging to the public administration and needs to be viewed as a paradigm on its own. Preceding discussions demonstrated that academics and practitioners have changed conceptual preferences on administrative science at different epochs of history. The adoption of ICTs in the running of government has changed its character (Mukonza, 2014).

\section{Paradigm 9: Public Value as an Emerging Paradigm in Public Administration}

In search for meaning and direction in administrative science, public value as an emerging paradigm attracts a considerable amount of interest among scholars and practitioners (Alford \& O’Flynn, 2009; Benington, 2009; Bojang, 2021; Bozeman, 2002; Fukumoto \& Bozeman, 2019; Jørgensen \& Bozeman, 2007; Moore, 1995; Rutgers \& Overeem, 2014). Public value management concerns government activities and service delivery, new thinking for public sector managers (O'Flynn, 2007). This paradigm is 'post competitive that signals the achievement of much broader social outcomes for society. This made Barry Bozeman concludes that "public value management is the most important topic in public administration and policy studies, while Alford \& Hughes (2008) pronounced it as the next phase of management.

Public value management emerges in response to the 'one best way' orientation of the previous management paradigm. Public value management calls for relevant stakeholders to collaborate effectively to solve societal problems. Unlike NPM, public value focuses on the collective aspirations of society (O'Flynn, 2007). Moore (1995) argues that the role of public sector managers is to create value for society. Moore's strategic framework concerns three domains that must be aligned to each other: (1) recognizing the public value an organization seeks to produce; (2) the 'sources of legitimacy and support' that are relied upon to authorize the organization to take action; and (3) the resources necessary to sustain the effort to generate that value (Mazzucato \& Ryan-Collins, 2019). Figure 1 illustrates the strategic triangle.

The focus of the strategic triangle is on public sector managers to guide their actions and activities. It is significant for public managers to be specific about the goals they seek to achieve, canvass support from relevant actors, and tap resources to achieve their goals (Moore \& Khagram, 2004). From the public value literature, two schools can be found. First, Moore's proposition of public value management as a practical guide for public managers, and second is the Bozeman normative proposition of public value (Ćwiklicki, 2016). Since Moore's seminal paper, the concept has been 'extraordinarily popular' (Rhodes \& Wanna, 2007) and numerous schools have written on it. However, it was criticized for its undemocratic nature of giving political power to unelected service managers (Rhodes \& Wanna, 2007). 


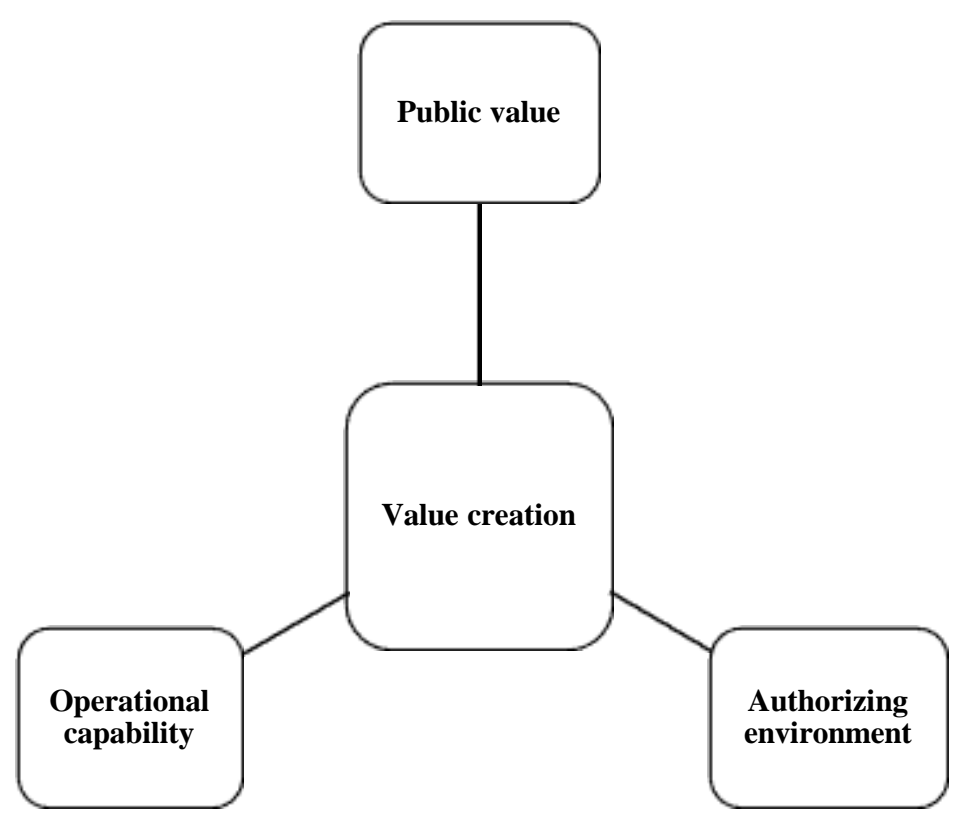

Figure 1. Strategic Triangle Moore (1995)

\section{Research Method}

This paper investigates the paradigmatic shift in public administration and determines if the 'Public Value Management' represents a new paradigm in the field of public administration. The study followed a historical approach to provide an accurate description and analysis of the current state as well as predicting its future course. Data for this study has been collected through a primary scoping of the literature on public administration. Database searches were conducted in the web of science, Social Sciences Index, SCOPUS journals, ISI Social Sciences Citation Index, and Google Scholar. Employing and searching the terms 'public administration', 'paradigms in public management', 'public value', 'public value management' 'e-Government', and 'public sector management' in conjunction. Research articles, policy documents, and working papers were selected based on relevance for in-depth analysis.

\section{Findings And Discussion}

It can be argued that public value represents the future of public administration. The idea of public value management offers an inspirational viewpoint on the function of public sector organizations (Benington, 2009; Moore, 1995) and a productive substitute area of study to better comprehend public sector management (Cordella \& Bonina, 2012). Moore's idea has gained prominence among scholars, service managers, and practitioners alike. The core idea of public value management centers on the strategic triangle which encompassed three factors that must be aligned with each other (e.g. see figure 1). 
This study shows that public value is not only an emerging paradigm in public administration but also the future. The study also found out that public value is the next big thing for governments aiming to deliver better public service. These findings are corroborated by a plethora of scholars (Benington, 2009; Bojang, 2021; Cordella et al., 2018; Hartley et al., 2017; Jørgensen \& Bozeman, 2007). Others hailed public value as 'the next big thing in public administration' (Talbot, 2009). It helps to deliver better public service that meets the expectations of citizens and at the same time enhances democratic governance. Historically, public administration has been criticized for failing to create value for society. The traditional public management paradigms create value in terms of efficiency in the production process. Public value approaches public administration to reframe public management paradigms, shifting the focus from cost efficiency to achievement of broader socially-expected outcomes. To meet societal needs, public administrations have to better understand what is socially expected and vigorously respond to changes in social expectations.

Despite its global popularity, public value remains elusive and devoid of clarity. Moore himself avoids discussing competing value approaches explicitly in public administration. Bozeman (2019) understands Moore's idea as a 'managerial' approach to public value, and he approaches it from a 'normative perspective', in that the notion of the public value is first and foremost about the content of values held by citizens and political actors. However, both frameworks overlap at certain points and diverge at others.

\section{Conclusion}

The field of public administration has gone through a plethora of paradigm changes. The frequent shift in paradigms has raised some probing questions among scholars of public administration. This study is significant as it demonstrates public value as the next phase of public management. The competing models and paradigms indicate the growth in administrative studies - which enhances empirical and theoretical improvement in the field. The public value paradigm challenges previous management paradigms which focus on efficiency of administration and individual needs. The new paradigm goes beyond this narrow definition of government role to seeking the collective good for society. Public value reformulates the governance structures and clearly defined the role of both government and citizens in codesigning and implementation of quality public services. Public value supporters recognize the unique dichotomy between the public sector and the private sector. These features are summarized in Moore's (1995) strategic triangle concept where he deliberates on the importance of aligning the authorizing environment, operational and administrative capabilities, and values, objectives, and mission to create public value. Overall, this study contributes to the literature and theoretical development of public value - the next big thing for governments aiming to deliver quality public service.

\section{References}

Alford, J., \& Hughes, O. (2008). Public Value Pragmatism as the Next Phase of Public Management. American Review of Public Administration, 38(2), 130-148. 
Vol. 2, No. 4, November 2021

https://doi.org/10.1177/0275074008314203

Alford, J., \& O'Flynn, J. (2009). Making Sense of Public Value: Concepts, Critiques and Emergent Meanings. International Journal of Public Administration, 32(3-4), 171-191. https://doi.org/10.1080/01900690902732731

Benington, J. (2009). Creating the Public in order to Create Public Value? International Journal of Public Administration, 32(3-4), 232-249. https://doi.org/10.1080/01900690902749578

Benington, J., \& Moore, M. H. (2011). Public value in complex and changing times. Public value: Theory and practice

Bojang, M. B. S. (2019). Challenges and Successes of E-Government Development in Developing Countries : A Theoretical Review of the Literature. III(Iv), 410-414.

Bojang, M. B. S. (2020a). A Model Proposal for E-Government Implementation in Africa: Adaptation from Delone and Mclean Information System Model. 20(5).

Bojang, M. B. S. (2020b). Beyond New Public Management Paradigm: The Public Value Paradigm and Its Implications for Public Sector Managers. Journal of Public Value and Administrative Insight, 3(2), 1-10. https://doi.org/10.31580/jpvai.v3i2.1381

Bojang, M. B. S. (2021). Appraising Public Value in the Public Sector: Re-evaluation of the Strategic Triangle. SEISENSE Journal of Management, 4(2), 1-10. https://doi.org/10.33215/sjom.v4i2.551

Bozeman, B. (2002). Public-Value Failure: When Efficient Markets May not do. Public Administration Review, 62(2), 145-161. https://doi.org/10.1111/0033-3352.00165

Bozeman, B. (2019). Public Values: Citizens' Perspective. Public Management Review, 21(6), 817-838. https://doi.org/10.1080/14719037.2018.1529878

Bromell, D. (2012). Creating Public Value in the Policy Advice Role: A Reflection from the Front Line. Policy Quarterly, 8(4), 16-22. https://doi.org/10.26686/pq.v8i4.4432

Cordella, A., \& Bonina, C. M. (2012). A public Value Perspective for ICT Enabled Public Sector Reforms: A Theoretical Reflection. Government Information Quarterly, 29(4), 512520. https://doi.org/10.1016/j.giq.2012.03.004

Cordella, A., Paletti, A., \& Shaikh, M. (2018). Renegotiating Public Value with Co-production. Creating and Capturing Value through Crowdsourcing, October, 181-203. https://doi.org/10.1093/oso/9780198816225.003.0008

Ćwiklicki, M. (2016). Comparison of Public Value Measurement Frameworks. Zarzadzanie Publiczne, 1(1(35)/2016), 20-31. https://doi.org/10.15678/zp.2016.35.1.02

Danziger, J. N. \& Andersen, K. V. (2002). The Impacts of Information Technology in Public Administration: An Analysis of Empirical Research from the "Golden Age" of Transformation. International Journal of Public Administration (25)5, pp.591-627 
Vol. 2, No. 4, November 2021

Denhardt, J.V \& Denhardt, R.B. (2007). The New Public Service: Serving, Not Steering. In M.E. Sharpe, Inc. All. Encyclopedia of Public Administration and Public Policy, Second Edition (Print Version). https://doi.org/10.1201/noe1420052756.ch268

Dickinson, H. (2016). From New Public Management to New Public Governance: The Implications for a 'New Public Service.' The Three Sector Solution, 41-61. https://doi.org/10.22459/tss.07.2016.03

Dimock, M. E. (1937). The Study of Administration. Political Science Quarterly, 56(4), 481. https://doi.org/10.2307/2143644

Fukumoto, E., \& Bozeman, B. (2019). Public Values Theory: What Is Missing? American Review of Public Administration, 49(6), 635-648. https://doi.org/10.1177/0275074018814244

Goodnow, F.J, (1900). Politics and Administration: A study in government. New York, Macmillan Co.; London, Macmillan \& Co

Gruening, G. (2001). Origin and Theoretical Basis of New Public Management. International Public Management Journal, 4(1), 1-25. https://doi.org/10.1016/S1096-7494(01)000411

Grönlund, A. \& Thomas A. Horan, T. A., (2004). Introducing e-GOV: History, Definitions, and Issues. Communications of the Association for Information Systems, Vol 15, pp. 713729

Gulick, L. \& Urwick, L. (1937). Papers on the Science of Administration. Institute of Public Administration, New York.

Hartley, J., Alford, J., Knies, E., \& Douglas, S. (2017). Towards an Empirical Research Agenda for Public Value Theory. Public Management Review, 19(5), 670-685. https://doi.org/10.1080/14719037.2016.1192166

Henry, N. (1975). Paradigms of Public Administration. Public Administration and Public Affairs, 35(4), 378-386. https://doi.org/10.4324/9781315530536-3

Hood, C. (1991). A Public Management for All Seasons? Public Administration, 69(1), 3-19. http://dx.doi.org/10.1111/j.1467-9299.1991.tb00779.x

Hood, C. (1995). The New Public Management in the 1980s: Variations on a Theme. Accounting, Organizations and Society, 20(2-3), 93-109. https://doi.org/10.1016/03613682(93)E0001-W

Jørgensen, T. B., \& Bozeman, B. (2007). Public Values: An Inventory. Administration \& Society, 39(3), 354-381. https://doi.org/10.1177/0095399707300703

Jørgensen, T. B., \& Rutgers, M. R. (2015). Public Values: Core or Confusion? Introduction to the Centrality and Puzzlement of Public Values Research. American Review of Public Administration, 45(1), 3-12. https://doi.org/10.1177/0275074014545781

Kraemer, K. L., et al. (1978). Local Government and Information Technology in the United 
Vol. 2, No. 4, November 2021

States. Paris: OECD Informatics Studies

Moore, M.H. (1995). Creating Public Value-Strategic Management in Government

Mazzucato, M., \& Ryan-Collins, J. (2019). Putting Value Creation Back into "Public Value": from market-fixing to market-shaping | UCL Institute for Innovation and Public Purpose. UCL Institute for Innovation and Public Purpose.

Meynhardt, T. (2009). Public Value Inside: What is Public Value Creation? International Journal of Public Administration, 32(3-4), 192-219. https://doi.org/10.1080/01900690902732632

Moore, M. H., \& Khagram, S. (2004). On Creating Public Value: What Business Might Learn from Government about Strategic Management. Corporate Social Responsibility Initiative, 1-27.

Mukonza, R. M. (2014). E-Governance As a New Paradigm in Public Administration. Journal of Public Administration, 49(2), 499-511. https://doi.org/10.32702/2306-6814.2020.3.122

O’Flynn, J. (2007). From New Public Management to Public Value: Paradigmatic Change and Managerial Implications. Australian Journal of Public Administration, 66(3), 353-366. https://doi.org/10.1111/j.1467-8500.2007.00545.x

Rhodes, R. A. W., \& Wanna, J. (2007). The Limits to Public Value, or Rescuing Responsible Government from the Platonic Guardians. Australian Journal of Public Administration, 66(4), 406-421. https://doi.org/10.1111/j.1467-8500.2007.00553.x

Rutgers, M. (2010). Theory and Scope of Public Administration: An Introduction to the Study's Epistemology. The Foundations of Public Administration Series, 1(c), 1-45.

Rutgers, M. R. (2015). As Good as It Gets? On the Meaning of Public Value in the Study of Policy and Management. American Review of Public Administration, 45(1), 29-45. https://doi.org/10.1177/0275074014525833

Rutgers, M. R., \& Overeem, P. (2014). Public Values in Public Administration. Journal of Public Administration Research and Theory, 24(3), 806-812. https://doi.org/10.1093/jopart/muu017

Stoker, G. (2006). Public Value Management: A New Narrative for Networked Governance? American Review of Public Administration, 36(1), 41-57. https://doi.org/10.1177/0275074005282583

Talbot, C. R. (2017). Measuring Public Value - A Competing Values Approach. March. https://doi.org/10.13140/RG.2.2.36824.90888

Turell, A. (2017). Applying Public Value Management Theory to Procurement. CIPS Knowledge download that displays a CIPS CPD icon. Policy paper

Waldo, D. (1968). Scope of the Theory of Public Administration. In: J.C. Charlesworth (ed.), Theory and Practice of Public Administration: Scope, Objectives, and Methods. Philadelphia: The American Academy of Political and Social Science 
e-ISSN: 2746-1351

Vol. 2, No. 4, November 2021

Willoughby, W. F., (1927). Principles of Public Administration. The Johns Hopkins Press. Also in American Political Science Review, 22(3), 769-770. doi:10.2307/1945638

Wilson, W. (1887). Political Science. Political Science Quarterly, 2(2), 197-222.

\section{Copyrights}

Copyright for this article is retained by the author(s), with first publication rights granted to the journal.

This is an open-access article distributed under the terms and conditions of the Creative Commons Attribution license (http://creativecommons.org/licenses/by/4.0/) 